\title{
Assessing Teachers' Beliefs and Awareness of Integrating Grammar and Teaching About the Reading
}

\author{
Gemechis T. Chali
}

\begin{abstract}
Teachers' beliefs in any field are thought to have a profound influence on their practical decision making. This study examines teachers' beliefs and awareness of integrating grammar and reading in the language teaching. Ten EFL teachers were observed for 1260 minutes and similar participants engaged on an FGD to express their beliefs. The study also employed the third data gathering tools, the document review. The result of this study reveals that teachers hold a positive beliefs about grammar and teaching about the reading in one way. Their awareness and techniques of making a link between grammar and reading is too low in the other way. However, this came to show change and steadily growing after the intervention and training on integration of the skills. It is evident that the lack of awareness to integrate the grammar and reading and poor techniques highly affect teachers' beliefs of grammar and teaching about the reading. The major finding reveals that improving teachers' awareness to integrate grammar with reading at sentence, or paragraph or essay/text levels can enhance the teachers' productivity. Based on the finding this paper suggests that attempts should be made to teach integratively either by using the existing text or by adapting the materials. Furthermore, teachers would be encouraged to foster the techniques to integrate grammar with reading. The curriculum designers should play their role since most of the existing reading texts failed to inspire the teachers to integrate the reading and grammar in the language class. Findings of the study may have important implications for EFL teachers and practitioners.
\end{abstract}

Keywords: Teachers' beliefs and awareness, teaching grammar and reading, integration

DOI: $10.7176 / \mathrm{JEP} / 10-25-04$

Publication date:September $30^{\text {th }} 2019$

\section{Introduction}

\subsection{Background of the study}

This article is based on the premise that EFL teachers' beliefs and awareness of making an integration between the reading and grammar is much noteworthy to improve language teaching. Despite there is an agreement on the importance of grammar teaching (Ellis, 2002; Crytal, 1996; Thornbury, 1999), there are erratic research on the an integration of grammar and reading. However, there are several works on the integrations of the macro skills (reading, speaking, writing and listening). In this regard, Mitchell (2000, p. 27) highlights that 'grammar teaching needs to be supported and embedded with meaning-oriented activities and tasks, which give immediate opportunities for practice and use'. For Mitchell, the concept embeddedness is a synonymous with integration in that context of the study. Borg and Burns, (2008) explored the beliefs of ELT professionals regarding the integration of Grammar with other skills in the adult classrooms. In their study they included many instructors from different parts of the world, but excluded the Africa region. Like, the Mitchell's their report indicated the importance of integration to improve the language. The current study is designed to reveal the teachers' awareness and techniques of integration, at least different from Borg and Burns, (2008) in two major things. Firstly, they conducted with the teachers from the context of ELT, but the current teachers worked with teachers who had no ELT training background. The second, they reported integration of grammar with all macro skills, but the current study is only ongoing with the reading skills. For this study, "Grammar in Reading and Reading in Grammar" works well when the teachers are aware of it.

No area of second and foreign language learning has been the subject of as much empirical and practical interest as grammar teaching (Crystal, 1996; Ellis, 2002; Thornbury, 1999; Nassaji and Fotos, 2004). Grammar is not something like an independent element or self-sufficient to work alone. It is more realistic to regard grammar as an accumulation of different elements, some more systematic than others, some linked together tightly or loosely, some completely independent and detachable. In their study, (Jean \& Simard) conclude that grammar teaching/learning is salient, but teachers and learners do not enjoy doing it (2011). Some EFL teachers think that grammar is full of word usage in which students or teachers should work to split those words. And some still do not enjoy grammar teaching finding that it is the baggage of rules and boring. There are still groups who make their body sick because of grammar. De Capua, A. (2008) states grammar:

For native speakers of any given language, grammar often represents to them the great "mystery" of language, known only to language specialists or those of older generations, the ones who really know what is "right". Many feel that "grammar" is something that they were never taught and that feel they therefore "don't know." Grammar is also often linked to both explicit and implicit criticisms of people's use or "misuse" of language, which may have created a sense of resentment or frustration with the notion of grammar. 
Loewen et al, (2009) conclude that there is perceived usefulness of grammar teaching for language production. Bernat \& Lloyd, (2007) state that the most important part of learning a language is the learning of its grammar. Related to the reading skills, although it is a broad concept, it is important to define from the literacy perspectives. According to Kern, (2010, p. 39):

combines a focus on language use in social contexts... with an additional component of active reflection on how meanings are constructed and negotiated in particular acts of communication.

For Kern, (2010) all the concerned bodies are responsible to focus on preparing learners for full participation in societies that increasingly demand multilingual, multicultural, and multi-textual competence. Teachers support students to read a high level text, firstly by preparing them to comprehend the text as it is read aloud, and then by giving them meaning cues to recognise and understand wordings within each sentence (Rose 2006).

While the issue of an integration raised, it could be more interesting and challenging as well. Most literature shows that practicing teachers are faced with a range of options for grammar instruction in their classrooms (Bernat \& Lloyd, 2007; Jean \& Simard, 2011). Lack of making an integration of the grammar with the reading skill is one. Identifying such difficulties and being consciously aware of them would help teachers find ways of overcoming them and provide effective grammar instruction. Most teachers never prefer discrete way of teaching, though there are inconveniences to do so. Lack of experience and exposure could be among the blocking reasons of making a link between grammar and reading to teach their lesson. However, these are not the only affecting factors.

Students must read about what they hear and talk about; they must write about what they read and hear and talk about; they must talk about what they read and write and hear. At secondary school of Ethiopia, the curriculum of the language has not been geared towards descriptive (MoE, 2017). The teachers' way of teaching is very traditional and teacher centered; teachers' taking time (TTT) dominates the classroom. The teachers are less creative to try to practice an integration between grammar and reading. A range of linguistic and methodological frameworks for integrating grammar work into the L2 learning process exist: lexical approaches (Little 1994), systemic-functional linguistics (Burns 2003), task-based learning (Ellis 2003), discourse approaches (CelceMurcia and Olshtain 2000) and communicative language teaching generally (e.g. Johnson 1982). All of the above represent attempt to make learning grammar part of some broader linguistic, contextual, and communicational phenomenon. Although many things have been said about the improvement of grammar and reading, there are scanty works done to making a link between grammar and reading. That is why mainly this article is limited to the study of EFL teachers awareness and techniques to improve teaching about reading and grammar.

In addition, the EFL teachers in secondary school do have a scarcity of critical knowledge and skill gap on the teaching of grammar and using flexible reading strategy as well. Heugh, et.al, (2007: 107) reports Ethiopian teachers are poor in English language because English is 'a foreign language and, hence, they have no opportunity to practice'. MoE (2017) also reports that language teachers' performance is below the standard. They hardly communicate and convey meanings in real communications due to lack of proper grammar and poor reading strategy. When asked to write a letter, they draft it several times, because their grammar cohesion and coherence skills for writing ability is below the standard. They are dissatisfied with their grammar capacity, and less confident to convey the meaning very well. For instance, the EFL teachers misuse of active and passive voices both in spoken and written communications unintentionally offend the readers and listeners of their materials. Teachers' lack of knowledge in reading development and methodologies critical affects the education. Teacher educators should be aware of the beliefs that teachers possess such as filtering mechanisms to accept or to reject new information (Kumaravadivelu 2012).

\subsection{The purpose and the rationale of the research}

The main objective for this article was to assess the teachers' awareness and techniques of making a link between grammar and reading while teaching English language. Despite there are several findings on an integration of the macro skills, there is a scarcity in the areas of making a link between grammar and reading. A few studies showed the combination of grammar with reading will improve the language. For instance, (Alderson, 1984; Shiotsu \& Weir, 2007; Urquhart \& Weir, 1998). They found that though grammatical competence is presumed to be indispensable for identifying syntactic relations of sentence components, there has been a little research on how readers' knowledge of grammar contributes to L2 reading comprehension. Their finding was limited to ESL students in primary schools, whereas the current study focused on the EFL teachers of the secondary schools of Ethiopia. The other study was (Borg, S. \& Burns, A. 2008). They conducted on 176 teachers of adults from around the globe to better understand their beliefs in the area of grammar integration with other skill, but Africa was excluded. They collected the data from New Zealand, Australia, Asia, Europe and South America. They reported that the two most prevalent beliefs when teaching grammar are, on the one hand, that teachers favor explicit grammar teaching and on the other, that they favor integration of grammar with other skills. Rand's (2016) work Webinar presentation about integrating grammar with reading and other skills is the other good model for this article. She prepared a text with different dialects of English, such as Jamaica, America, Uk, Europe and Australia. She found that such texts will improve the teachers' and students' awareness of language in general. 
Although there were a number of articles done in the areas of micro skills integration (Thornburry, 1999; Ellis, 2006; Nasaji and Fotos, 2004;Myhill, 2010; Watson, 2012), there were no studies in the areas of grammar and reading integration as far as the knowledge of the researcher is concerned.

It might be too ambitious that integrating of reading and grammar could benefit teachers and students from four perspectives (arguably more than that). Firstly, when teachers teach reading by integrating with the grammar students will learn the uses of the grammar more, but with very less attention. The vice versa works similar. For instance, the teacher never asks what is passive voice or present simple while the text presents/reports about the bank robbery to the police. The second, the students could get the opportunity of understanding the gist or the specific idea of the passage while working on some grammatical items in the text. For example, the teacher asks the students to identify verbs of reporting in the paragraph. They also notice the relationship of 'reporting verbs plus that' (eg, ... say that..., ....report that..., ...claim that...). The third benefit of integration, it is the color of diversity. Students better learn from differences not always homogeneousness. Lastly, both teachers, students and curriculum designers effectively use their time, energy and space by minimizing, if not avoiding, discrete way of teaching and learning.

\subsection{Research Questions}

a) What are the teachers' beliefs and awareness of making an integration between grammar and reading in teaching the language? How about the techniques used?

\section{Literature Review}

\subsection{Theoretical Context of an integration and beliefs}

Today, there is one prevalent thought that almost all language teachers share about language teaching. They said teaching grammar in an isolated way is not "effective". As early as the 1970s, many researchers and methodologists noted that the teaching of language skills cannot be conducted through isolable and discrete structural elements (Stern, 1992). However, most of them centered at the macro level integration. Larsen-Freeman said that " teaching grammar means enabling the language students to use linguistic forms accurately, meaningfully, and appropriately" (2001). Among the few scholars, Borg and Burns, studied whether teachers integrated grammar with other skills is important or not, (2008), Randi Reppen publishes on the Webinar "the importance of integrating grammar in the advancement of writing skills" (2016). She has concluded integrating grammar in the advanced writing/reading is so important. Myhill, reported teaching grammar by linking with writing could improve the language learning (2004).

In fact, Pajares (1992) goes further and claims that "[f]ew would argue that the beliefs teachers hold influence their perceptions and judgments, which, in turn, affect their behavior in the classroom, or that understanding the belief structures of teachers and teacher candidates is essential to improving their professional preparation and teaching" (p. 307). Hence, it is really not surprising that this area of research is making an impact in language teaching. Nespor (1987) and Pajares (1992) in separating out conceptual elements of belief what teachers believe that grammar teaching 'is' from evaluative elements if and how teachers believe that teaching grammar is useful. A further facet of belief identified by Nespor, the 'affective' element, has been reported on by Watson (2012), drawing on the same dataset that informs this paper.

Teachers usually report they are forced to teach grammar in explicit way because their students want them to do so. However, some scholarly works indicate that teachers by themselves are traditional grammar teachers. For example, (Jean and Simard) found teachers remain traditional for the most part, with grammar teaching centered on accuracy of form and rule learning, and with mechanical exercises seen as the way to bring about the learning of grammar (2011). Despite they seemed to neglect grammar teaching, it was reported by majority of the teachers use grammar for exams. For example, during FGD session Dadhi says:

I always use grammar and reading to make the tests and the exams. But, my strategy is very

old and traditional. I have no adequate techniques of integrating the grammar and reading in

language teaching. I teach them by isolating.

There is no experience and effort to work on the integration of the grammar and the reading from the teachers side at most. In a nutshell, a prescriptive theory of a grammar-writing relationship would argue for the importance of grammar in securing correctness in written expression; whilst a descriptive theory of a grammar-writing relationship would argue for the importance of grammar in illuminating how written text generates meaning in different contexts (Myhill, 2010). The very term 'grammar' itself means different things to different people, and it is the different views of what grammar is which shape many of the opposing views this article. For example for Crystal, grammar is 'the business of taking a language to pieces to see how it works' (2004, p. 10) and traditionally this has involved focusing on morphology, the structure of words, and syntax, the structure of sentences (Carter and McCarthy, 2006: 2). Similarly, an integration of grammar with reading would be the base for the students language improvement and teachers' productivity. 


\section{Methodology}

\subsection{Research design}

This study was aimed to investigate the teachers' beliefs and awareness of integrating grammar and reading. It also sheds some light on the techniques used by the teachers. The qualitative inquiry is valuable to this study for several reasons. First, qualitative research, being a naturalistic approach, allows exploring phenomena in context specific settings (Creswell 2007). Moreover, the centeral part of the study is to understand teachers' beliefs and awareness teaching reading and grammar. Studying their experiences is more interesting. In regards to the paradigm, it focuses on their experience, beliefs and practices to pave the ways to bridge the research gap. The intention for this article was not only to discover the teachers' beliefs and awareness of integrating the grammar and the reading. Furthermore, it has been attempted to alleviate the problems by intervention and training, though small scale. Educators do not simply want to know how the world "out there" is (Biesta, G. J. J. \& Burbules, N. C., 2003). They want knowledge that can inform their actions and activities.

\subsection{The research site}

The investigation was conducted in secondary schools (Grade 9 and Grade10) of the six woredas of Jimma Zone in Oromia Regional State, Southwest Ethiopia in 2017-2019 academic year. There are about 21 woredas in the Zone in which the schools are on different geographical locations, where some are remotest from center. Since it was difficult and unexpected to address all the the schools, six schools were purposely chosen. The four major reasons for selecting this six schools in the research site were: 1) female teachers' participatory. In most of the schools, there is scarcity female language teachers. So, the school selection was made to include the females. 2) proximity: relative to the other zones of Oromia Regional State, Jimma is somehow near to the working area of the main researcher. This enabled the researcher to manage the data collection and to visit the areas with the average cost of transportation, energy and time. It also minimizes the expense for the participants during the data collection. This enabled the assistant researchers and main researcher to visit one place at least twice and more to confirm the ongoing of the research. 3) accessibility: since the main researcher is the teaching staff of Jimma University, there are some teachers who are the ex-students of Jimma University, perhaps some of them were in the department of English language and literature. The majority of the secondary school teachers including other subjects also attend Jimma university for upgrading. This has helped the main researcher to establish rapport with most of the respondents in the woredas. 4) trustworthiness: as the study employed the qualitative research paradigm, it would be much important to trust the respondents and the respondents also need to trust the researchers.

\subsection{The participants}

Twenty four teachers engaged on the training and Focus Group Discussion (FGD) from the six woredas and six schools having different experiences of teaching. But, for the sake of the analysis and to keep uniformity with other data gathering tools only ten teachers were selected purposively for both FGD and observations analysis. With regards to the questionnaires, 50 questionnaire was administered to them, but 42 returned. Some pictures and videotapes of the scenes were taken based on their agreement. The following is the respondents' names, sex, teaching experience and other variables. Their names are pseudonyms.

\begin{tabular}{|c|c|c|c|c|c|c|c|c|}
\hline No. & $\begin{array}{l}\text { Teacher's } \\
\text { pseudonyms }\end{array}$ & Sex & $\begin{array}{l}\text { Teaching } \\
\text { experience }\end{array}$ & Qualification & $\begin{array}{l}\text { Secondary } \\
\text { school }\end{array}$ & $\begin{array}{l}\text { Grade } \\
\text { teaching }\end{array}$ & $\begin{array}{l}\text { Pre- } \\
\text { observation }\end{array}$ & $\begin{array}{l}\text { Post- } \\
\text { observation }\end{array}$ \\
\hline 1. & Dadhi & $\mathrm{M}$ & 4 years & $\mathrm{BEd}$ & Yabbu & 9 & $45 \mathrm{~m}$ ' & $90 \mathrm{~m}^{\prime}$ \\
\hline 2. & Jaba & $\mathrm{M}$ & 28 years & $\mathrm{BEd}$ & Gembe & 9 & $40 \mathrm{~m} '$ & $90 \mathrm{~m}^{\prime}$ \\
\hline 3. & Barite & $\mathrm{F}$ & 29 years & $\mathrm{BEd}$ & Gembe & 9 & $37 \mathrm{~m}^{\prime}$ & $* * *$ \\
\hline 4. & Tola & $\mathrm{M}$ & 35 years & $\mathrm{BEd}$ & Agaro & $9 / 10$ & $40 \mathrm{~m}^{\prime}$ & $90 \mathrm{~m}^{\prime}$ \\
\hline 5. & Kadir & $\mathrm{M}$ & 18 years & $\mathrm{BEd}$ & Sarbo & 9 & $40 \mathrm{~m}^{\prime}$ & $90 \mathrm{~m}^{\prime}$ \\
\hline 6. & Ganame & $\mathrm{F}$ & 34 years & $\mathrm{BEd}$ & Sarbo & 9 & $45 \mathrm{~m}^{\prime}$ & $90 \mathrm{~m}^{\prime}$ \\
\hline 7. & Bontu & $\mathrm{F}$ & 24 years & $\mathrm{BEd}$ & Jiren & 9 & $45 \mathrm{~m}^{\prime}$ & $90 \mathrm{~m}^{\prime}$ \\
\hline 8. & Lense & $\mathrm{F}$ & 30 years & $\mathrm{BEd}$ & Saqqa & $9 / 10$ & $38 \mathrm{~m}$ ' & $90 \mathrm{~m}^{\prime}$ \\
\hline 9. & Hora & $\mathrm{M}$ & 20 years & $\mathrm{BEd}$ & Agaro & $9 / 10$ & $45 \mathrm{~m}^{\prime}$ & $90 \mathrm{~m}^{\prime}$ \\
\hline 10. & Chaltu & $\mathrm{M}$ & 13 years & $\mathrm{BEd}$ & Jiren & 10 & $40 \mathrm{~m}^{\prime}$ & $90 \mathrm{~m}^{\prime}$ \\
\hline & \multicolumn{6}{|l|}{ Total } & $450 \mathrm{~m}^{\prime}$ & $810 \mathrm{~m}^{\prime}$ \\
\hline
\end{tabular}

Table1: Participants' profiles

\subsection{Instrumentations}

The classroom observations, Focus Group Discussion (FGD), and the document review were employed. The majority of the observees were videotaped during the pre and post-observations. This helped to investigate the awareness and techniques of the teachers in making a link between grammar and the reading. Integrating the skills means that teachers are expected to work at the level of realistic communication. Since this type of activity could 
not be only confirmed by what the teachers said (FGD), employing observations and reviewing some documents helped as well. An observation is an effective type of tool to investigate teachers' practices in the classroom. For instance, (Kuzborska, 2011) has attempted classroom observation as the instrument to explore what teachers practice in their classrooms. According to Nunan (1992) "there is no substitute for direct observation as a way of finding out about language in classrooms" (p.76). The observation also helped to justify their answers during the FGD and how they integrate the grammar with reading in their classes. The document review has been made to reflect to what extent the material are suitable and proof how the teachers decides their performance. Some texts were purposefully selected for review and intervention. The Focus Group Discussion (FGD) helped to probe the participants personal profiles and their beliefs and awareness of making a link between grammar and reading.

\subsection{Data analysis and procedure}

The study employed the qualitative data analysis approach by combining the deductive and inductive ways of the data analysis. Lincoln and Guba, (1985) suggest employing deductive and inductive data analysis is advisable. This type of data analysis could be advantageous to perform data gathering and analysis simultaneously during the fieldwork. The existing frameworks from the literature (e.g., Grabe, 2009; Hudson, 2001; Krashen, 1993; Urquhart $\&$ Weir, 1998) supports they used to analyze the data. For instance, to analyze the beliefs of teachers to teach grammar and reading, the deductive approach was used. The current study employed the inductive data analysis for the better investigation of the awareness of the teachers to integrate grammar and reading teaching. Therefore, the teachers' full working experience, interest and the setting in which they work were considered under the analysis of inductive data analysis. Once the data gathering tools were identified, they were organized in a systematic and logical ways. Their replies and discussions were constructed with high care during FGD. The preand post-observations were held in a very friendly environment to inspire the teachers to teach their own lesson. The document review analysis intervention was made on the selected texts using the techniques for integration instead of their former way (isolated). Finally, participants' profile were organized to highlight their teaching experiences, Grades, and practices.

\section{The results of the study}

\subsection{Teachers' background data and related issues}

The teachers' profile revealed that they had got different teaching experience (the minimum 2 years and the maximum 35 years). Although the number of female teachers in the country is very less, it has been tried to work with both with fair number (4:6). Despite there is a scarcity of English language teachers with a minimum requirement of a degree across the country, the study involved the first degree holders, bachelor of education (BEd). However, the participants upgraded their qualification from lower levels, like from Teachers' Training Institute (TTI). In regards to the Grade they teach, all teachers do have the experience of teaching the two Grades (9 and 10). This helped the respondents to have similar understanding about Grade 9 and 10. Hence, their reported experience of teaching included the primary schools as well. All of the teachers had taken few grammar courses in the college, and they had got no on job training to improve their knowledge of English.

\subsection{Results of Focus Group Discussion (FGD)}

Randi reports it is important to show the positive effect of integrating grammar with reading and other skills (2016), like her, Borg and Burns, (2008) found an integration of grammar with other skills by teachers showed an important effect on language teaching. In the current study, since the FGD session was conducted in between the pre- and the post-observation sessions, it was a good opportunity to evaluate their understanding of integration and the techniques used before and after. Because there was an intervention session after the FGD. It was evident during the pre-observations, teachers had no clear idea about the integration of the reading and grammar, leave alone techniques to integrate them.

Five of the discussants reported that they believed teaching grammar and reading in integrating way is very important and helpful. They said that teaching grammar is about learning how words work in relation to one another to make meaning of a word, sentence, paragraph, and whole-text levels. They always felt that grammar could come in the reading or with reading. But, they stressed that there were no rich experiences and exposures and less motivation to do so. Besides, they criticized the textbooks were also not convenient to present in an integrative way. Chaltu reported this way:

I used to teach separating grammar lessons from teaching reading and other skills, in fact. I encountered many problems: The grammar sessions were boring and mechanical, which reduces students' chances to use the language in lifelike situations.

It was explained by most of the teachers $(7 / 10)$ that they have a positive beliefs about grammar and teaching reading. They also noticed reading and grammar are salient in the language teaching. One of the discussants said:

Teaching grammar, or reading in the language is like the central nervous system. With the dearth of grammar, it is almost impossible to transfer our message. Similarly, no teaching reading means 
no way to receive others' view. Though I believe they are crucial to join the today's world, I have inadequate understanding.

Despite the majority of them (8/10) reported the importance of grammar and reading in the language, they never replied using of integration or implementation of techniques. Almost all of them (9/10) agreed their teaching was isolated. Most of them stressed they lacked skill or knowledge for teaching the language via integrating though they felt their importance. Here, quoted from Tola:

Grammar and reading teaching in foreign language are like backbone. Missing to teach those two items (grammar \& reading) were like missing the two key parts in the language teaching learning process. It was not only about teaching the grammar and the reading, but it affected the total language. However, I have no clear experience to teach them integratively. I usually taught them in separate ways.

Lack of interest as a teacher and inadequacy of the knowledge to be aware and implement were reported. Six teachers underlined the reading and the grammar they have been teaching is what they had been taught some years back. Their experience and knowledge of reading and grammar they owned directly affected their awareness and beliefs of teaching. Surprisingly, they explicitly spoke most of them hunt job advertisement after the class to change the teaching profession.

Not only lack of awareness and techniques, teachers also criticized the textbook was not suitable to teach in integrative ways. They said the textbook also played a negative role in regards to their awareness of integration. Seven of them reported despite there were some reading texts to implement the integration, the texts were not up to the level of the students. They said the reading texts were sometimes below their age, and the other time very difficult. Most of them (8/10) stated they dreamed to teach reading and grammar in English, but they failed to do so. Some of them felt ashamed for the lack of the consistency between their beliefs and the practice. As a result of this, their poor awareness and techniques of an integration of the skills affected language teaching. They showed their regret that their failure to teach effectively directly connected to the failure of students' language.

During the FGD they (6/10) strongly criticized the text designers, it did not only demotivate their language teaching, but some of the texts had a negative long lasting effect on the teaching. According to them, they were not aware of integrating or using the techniques of integration, when the texts are unfamiliar. To that end, "most of the reading texts were imported with foreign culture and experience", said Kadir. "Reading must be related to the prior knowledge of the students, but some of the texts are not good", said Tola. "There are contents about the wedding and dancing ceremony of Hong Kong and China" said Barite. She agrees it is good to know the culture of Chinese and others through reading, but the text should be adapted. However, there need to be a reading text that would enable to exercise students' conscious and reservations about the culture disparities.

The participants (3/10) also reflected their worries that some contents implicitly forces them to teach political issues. "The textbook is full of biased stories and controversial, in which nations and nationalities of Ethiopia are unequally treated", said one of them (eg, Grade 9 p. $155 \& 181)$. They informed this type of reading contents triggered conflicts and disagreements among the people. They spoke they are responsible as they all teach youngsters who ask many questions and sensitive to the reading.

In general, teachers reported their beliefs and awareness of making a link between grammar and reading was below the expected though improvements were reported after post-observations. In fact, the FGD report revealed teachers had several impeding factors to exercise the integration of reading and grammar. Despite the FGD distinguishes lack of experience, inadequacy of knowledge/skill, no training, unattractive texts, and poor motivation as the main blocking factors to be aware and implement integration, the other impeding factors would not be neglected by any means (students' background, no exposure to English, low salary).

\subsection{Result of classroom observation}

The next data gathering tool will briefly present the summary of the results obtained from the pre-and postobservations. The observations were conducted in the second semester of 2017/18 and 2018/19 for 1260 minutes with ten EFL teachers (cf. detail Table 1). An observation is a systematic method of collecting data that rely on a researcher's ability to gather data through his or her senses (O'leary, 2004, p.170). Since people do not always do what they say they do, observation is an important instrument to get a direct information about teachers and classroom events (Cohen et. al, 2005). In the next table, some selected reading topics' analysis of the pre-and post-observations are presented in summarized way. Next to that the two teachers' (kadir and Dadhi) presentation on the same lesson through integrating the reading and the grammar from the Grade 9, page 32 follows. This will be done to probe the improvements made due to the training and intervention on the integration in particular and the L2R:R2L in general. 


\begin{tabular}{|c|c|c|}
\hline $\begin{array}{l}\text { The teachers aware } \\
\text { Typical reading } \\
\text { tasks }\end{array}$ & $\begin{array}{l}\text { ess and techniques used to integrate the readin } \\
\text { Teacher's role in pre-observation }\end{array}$ & $\begin{array}{l}\text { and grammar while teaching the language } \\
\text { Teacher's role in post-observation }\end{array}$ \\
\hline 1.Causes/effect & $\begin{array}{l}\text { - Media TV and Radio, Gr9, p. } 239 \\
\text { "read at home and do the comprehension } \\
\text { questions" }\end{array}$ & $\begin{array}{l}\text { Extract from Nelson Mandela Gr10, p.39. } \\
\text { "Who is Mandela? Why was he in jail?" }\end{array}$ \\
\hline 2.Process/procedure & $\begin{array}{l}\text { - Ghana,Gr10. p. } 229 \\
\text { "do the vocabularies at home" }\end{array}$ & $\begin{array}{l}\text {-Arts and Crafts Club Gr9, p. } 41 \\
\text { "divided paragraphs among them; to } \\
\text { identify the central message; to sort out } \\
\text { all connectors of process: firstly, then, } \\
\text { after that, next...." }\end{array}$ \\
\hline 3.Exemplification & $\begin{array}{l}\text { - Facts about Hong Kong, Gr9,p.241 } \\
\text { "read in pair and groups and gave home } \\
\text { works" }\end{array}$ & $\begin{array}{l}\text {-East African Athletes, Gr10,p.3 } \\
\text { "Who are the known athletes in Ethiopia, } \\
\text { Africa and the world; make sentences by } \\
\text { using the words: for example, for } \\
\text { instance; use passive and active voices in } \\
\text { sentences" }\end{array}$ \\
\hline 4.Classification & $\begin{array}{l}\text { - Different forms of energy Gr10, p. } 247 \\
\text { "just read it yourself and do the } \\
\text { comprehension" } \\
\text { - The world in danger, Gr9,p. } 198 \\
\text { "what is the meaning of world in danger?" }\end{array}$ & $\begin{array}{l}\text {-Breakthrough for Women's Soccer } \\
\text { Gr10,p.9 } \\
\text { "identify the dominating tenses, } \\
\text { cohesions, underlined passive and active } \\
\text { voices" }\end{array}$ \\
\hline 5.Description & $\begin{array}{l}\text { - People and traditional culture Gr9, p.2 } \\
\text { "what is tradition?" "What is culture?" } \\
\text { - Ceremonies around the world Gr10,p.212 } \\
\text { "read at home" }\end{array}$ & ------ \\
\hline 6.Narrative & $\begin{array}{l}\text { - Stigma and discrimination Gr9, p.245 } \\
\text { "read together and we do the tasks" }\end{array}$ & $\begin{array}{l}\text { - Ayantu to the rescue, Gr10, p.21 } \\
\text { "read independently and silently; } \\
\text { identified past simple tenses; reported } \\
\text { speech in past, modal auxiliaries, } \\
\text { verbs for reporting" }\end{array}$ \\
\hline 7.Argumentative & $\begin{array}{l}\text { - Education in Ethiopia- where is it going? } \\
\text { Gr10, p. } 244 \\
\text { No reaction about the reading from him. }\end{array}$ & ------- \\
\hline
\end{tabular}

Table 2: Analysis of pre-and post-observations

Below is the reading text from the textbook (Grade 9, p.32) in which the two teachers taught by integrating the grammar and the reading during the post-observation.

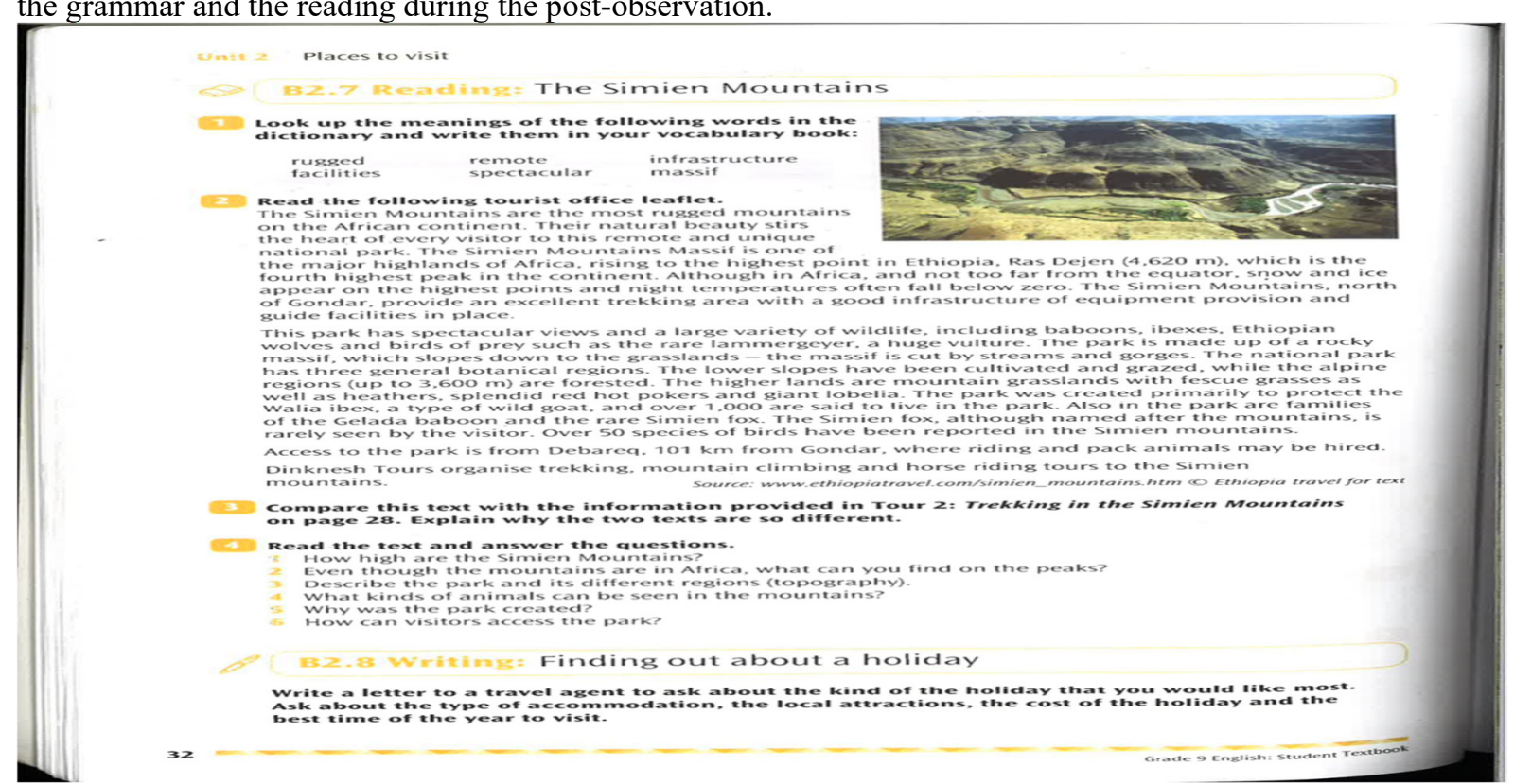

Fig 1: Reading text from Grade 9 for intervention 
Based on the above reading text, the two teachers' presentation result is analyzed as in the table below.

\begin{tabular}{|c|c|c|c|c|c|}
\hline Teachers' pseudo name & & dhi & Kadir & & \\
\hline $\begin{array}{l}\text { DGMT- Discrete Grammar Reading } \\
\text { Teaching } \\
\text { IGMT-Integrated Grammar Reading } \\
\text { Teaching } \\
\text { x-refers to what is observed }\end{array}$ & $\sum_{0}^{E}$ & $\sum_{\underline{O}}^{E}$ & $\begin{array}{lll}\text { DGMT- Discrete } & \text { Grammar } & \text { Reading } \\
\text { Teaching } & & \\
\text { IGMT-Integrated } & \text { Grammar } & \text { Reading } \\
\text { Teaching } & & \end{array}$ & 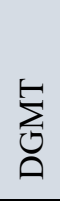 & $\sum_{0}^{\ominus}$ \\
\hline $\begin{array}{l}\text { "Reading and grammar" wrote on the } \\
\text { blackboard }\end{array}$ & & $\mathrm{x}$ & $\begin{array}{l}\text { "Reading a passage about Simien } \\
\text { Mountain" verbally. }\end{array}$ & $\mathrm{X}$ & \\
\hline "Be in a group of 5 to read \& understand" & & $\mathrm{x}$ & "where is Simien Mountain?" & & $\mathrm{X}$ \\
\hline $\begin{array}{l}\text { "Left } \& \text { middle row read the } 1^{\text {st }} \text { paragraph } \\
\& \text { the right row read the } 2^{\text {nd }} \text { paragraph". }\end{array}$ & & $\mathrm{X}$ & $\begin{array}{l}\text { "Today, you learn about description and } \\
\text { very important tense to read description }\end{array}$ & & $\mathrm{X}$ \\
\hline $\begin{array}{l}\text { "This passage contains some tenses. } \\
\text { While reading, identify the tense in the } \\
\text { passage." }\end{array}$ & & $\mathrm{x}$ & $\begin{array}{l}\text { "Now, you have } 15 \text { minutes to read." } \\
\text { Asked them to participate in the reading. }\end{array}$ & $\mathrm{X}$ & \\
\hline $\begin{array}{l}\text { "Can you count the number of verbs in } \\
\text { that tense?" Explicitly ask them to tell the } \\
\text { verbs. }\end{array}$ & $\mathrm{X}$ & & $\begin{array}{l}\text { "Now, how many sentences do you read } \\
\text { in the first paragraph?" }\end{array}$ & $\mathrm{X}$ & \\
\hline $\begin{array}{l}\text { "Why the writer dominantly uses present } \\
\text { verbs to describe" }\end{array}$ & & $\mathrm{x}$ & $\begin{array}{l}\text { "Can you write down the verbs in each } \\
\text { sentence and understand the meaning?" }\end{array}$ & & $\mathrm{X}$ \\
\hline $\begin{array}{l}\text { "Do you know the difference between } \\
\text { past and present verbs?" why the writer } \\
\text { uses the present verbs to describe? Why } \\
\text { not past? }\end{array}$ & & $\mathrm{x}$ & $\begin{array}{l}\text { "Very good; are, is, appear, fall" Do we } \\
\text { use them to narrate stories or to describe } \\
\text { places, people? }\end{array}$ & & $\mathrm{X}$ \\
\hline $\begin{array}{l}\text { "Why the writer dominantly used the } \\
\text { present verbs in the text?" }\end{array}$ & & $\mathrm{x}$ & $\begin{array}{l}\text { "what about the verb for the second } \\
\text { sentence? Which one is it? }\end{array}$ & $\mathrm{X}$ & \\
\hline $\begin{array}{l}\text { "The main purpose of the writer is to } \\
\text { describe the Semien mountain using } \\
\text { narrative. Is that True?" }\end{array}$ & & $\mathrm{x}$ & $\begin{array}{l}\text { "Their natural beauty...... Their refers } \\
\text { to?" }\end{array}$ & & $\mathrm{X}$ \\
\hline $\begin{array}{l}\text { "Can you describe your village using } \\
\text { present verbs?" }\end{array}$ & & $\mathrm{x}$ & $\begin{array}{l}\text { "Very good! The verb is stirs. What is the } \\
\text { meaning of stirs?" }\end{array}$ & & $\mathrm{X}$ \\
\hline $\begin{array}{l}\text { "Just use only present verbs to tell us } \\
\text { about your village. Tell means to } \\
\text { describe" }\end{array}$ & & $\mathrm{x}$ & $\begin{array}{l}\text { "Does the writer talk/narrate about the } \\
\text { past/ present/ the future?" Why? }\end{array}$ & & $\mathrm{X}$ \\
\hline $\begin{array}{l}\text { "Present verbs are formed from V1 and } \\
\text { they use to describe and talk about the } \\
\text { realities in the passage. }\end{array}$ & & $\mathrm{x}$ & $\begin{array}{l}\text { "what do you know about passive and } \\
\text { active voices? How do you form them? } \\
\text { What is the difference?" }\end{array}$ & $\mathrm{X}$ & \\
\hline \multicolumn{3}{|c|}{$\begin{array}{l}\text { Conclusion: 1) The passage is about Simien Mountain. } \\
\text { 2) the author used many descriptive words } \\
\text { 3) the author used present verbs } \\
\text { 4) the author used the structure of active and passive }\end{array}$} & \multicolumn{3}{|c|}{$\begin{array}{l}\text { The teacher stopped and invited students to ask } \\
\text { questions. One student wanted to know if they had } \\
\text { assignments. }\end{array}$} \\
\hline
\end{tabular}

Table 3: Analysis of integrating grammar with reading

Finally, the result of the pre- and the post-observations showed some differences. During the pre-observation, the teachers failed to implement in grammar teaching in embedded way. However, there were some paragraphs and essays which were convenient to present integratively. The pre-observation revealed the teachers usually gave reading as home take assignments and for exam preparations, especially Grade 10. During the postobservations, the majority of the observees (7/10) showed a positive welcoming to teach reading and grammar in integrative way. The study asserted although there was unfulfilled conditions to teach grammar and reading in integrated way, they did not totally ban effective grammar teaching to the students. The post-observation revealed designing such a training document continuously could enable to alleviate the problem of the language in general and inspire the teachers' skill of integration in particular.

\subsection{Result of the document review}

The guidelines for an integration of document review is mainly adapted from Borg and Burns, (2008) and Randi Reppen, (2016) Webinar presentation. Students' material, teachers' lesson plan and notes were used for the document review. The result of the document review showed that teachers overlooked the integration of grammar and reading. For instance, their weekly and monthly lesson plan gave less attention for grammar and reading 
teaching. Although there were different conducive texts in the textbook, teachers hardly used teaching via integration. No feedbacks were given to the students work on integration as well. Although there were inconvenience from the contents of the textbook, it did not totally block to teach by integrating the grammar with the reading. Finally, the result from the document review revealed teachers lacked awareness and techniques to integrate grammar and reading in their language classroom.

\section{Discussion and interpretations of the study}

The discussion focuses on two issues. In the first one, the study reveals that teachers hold a positive beliefs on the importance of grammar and reading teaching in secondary schools of Ethiopia. In the second it was found that their awareness and techniques of integrating grammar with reading in language classroom is poor. In relation to the first issue, different publications confirmed that teachers have strong beliefs of grammar teaching (cf. Pajares, 1992; Ellis, 2003; Thornbury,1999; Zain, M., \& Rohani, S. 2007, p. 1; Borg, 2006, 2003,1998). So, the current study is congruent with them that they hold strong beliefs of grammar teaching there are differences in teaching experiences, and various in working environment.

While coming to the second issue, integration, the result shows that teachers have lacked awareness and techniques to integrate the grammar and the reading in their class. But, this situation immediately started changing, that might be, after the training and the intervention. The findings of the current result is consistent with (Borg and Burns, 2008; Larsen-Freeman, 2003; Ellis 2006). Borg and Burns, (2008) concluded that there was the strong beliefs in the need to avoid teaching grammar in isolation and reported high levels of integration of grammar in their practices with other skills. Their study reported about176 English language teachers from 18 countries, but Africa not included. Most of the teachers have exposure to the ELT context and the integration was with all macro skills, whereas in the current study the teachers are in EFL context and only with reading skills. The current study findings also agrees with the findings of Larsen-Freeman, (2003). She stresses the job of the teacher is to combine various means of instructional options, for instance their concern with grammar (2003). The emerging of the integration task could also minimize the teachers' beliefs about grammar teaching are difficult and traditional. Grammar is of key significance for accuracy and correct language usage. It can act as an enabling skill and motivate students to some extent in their path to proficiency. Today, due to widespread use of tests as means of entering institutions, programs, as well as higher level education, which require the participants to act and perform accurately in these situations, students are expected to familiarize themselves with correct grammar. Thus, it necessitate for the educator to include grammatical proficiency as part of the curriculum Larsen-Freeman (2003).

The current study matches with the work of (Grabe, 2005, 2009; Jeon \& Yamashita, 2014). They found that regardless of the language to be learnt, successful reading comprehension is dependent on the grammar the reader knows, that is grammar plays a very important role in understanding texts, both for the first language (L1) and for the other languages.

The other important result about this finding is that the radical change of their interest to teach the grammar with reading after the training and intervention that they were postponing grammar and reading teaching previously. This is congruent with Mitchell (2000, p. 27) highlights, is that 'grammar teaching needs to be supported and embedded in meaning-oriented activities and tasks, which give immediate opportunities for practice and use'. The result revealed the grammar teaching is still sensitive especially for non-native (arguably), unless attention is given. The study totally indicated that teachers were not happy to teach prepositions, phrasal verbs and passive voices, but these became minimized during the post-observations. This is supported by Ellis that he found several areas in teaching grammar remain the focus of debate (2006).

The following techniques (cf. the Table below) were adapted from views of different scholars to improve the participants' awareness of integrating grammar and reading. Some of them were used by Burns and Borg, (2008) for embedding grammar in other skills, and others were from Randi's (2016) work to enable the teachers to integrate grammar in reading skills. 


\begin{tabular}{|c|c|}
\hline Ways of integrating & Descriptions \\
\hline $\begin{array}{l}\text { - Descriptive essay/text } \\
\text { - Narrative essay/text } \\
\text { - Cause and effect essay } \\
\text { - Planning } \\
\text { - An investigative story }\end{array}$ & $\begin{array}{l}\text { - The present verbs are mainly dominant; use vivid adjectives } \\
\text { - For narrative past verbs are expected; } \\
\text { - Look, for example the role of prepositions }(\ldots \mathrm{V} 1 / 2 \text { resulted } \\
\text { from ...; ...V1/2 resulted in.... } \\
\text { - Need to identify the future verbs; } \\
\text { - } \quad \text { Reporting verbs; passive/active constructions; }\end{array}$ \\
\hline - Reactive focus on grammar & $\begin{array}{l}\text { - Focusing on grammar in response to errors, questions and } \\
\text { difficulties which arise during skills work; }\end{array}$ \\
\hline $\begin{array}{ll}\text { - } & \text { Presenting grammar } \\
\text { through texts } & \\
\end{array}$ & $\begin{array}{l}\text { - Presenting grammar through texts chosen to } \\
\text { illustrate it }\end{array}$ \\
\hline - Grammar in context & $\begin{array}{l}\text { - Presenting and practising grammar by placing it in meaningful } \\
\text { contexts }\end{array}$ \\
\hline
\end{tabular}

Table 4: Techniques to integrate reading with grammar

In general, the study revealed that the participants benefited after the intervention and training of integration. Promising improvements were observed while inspiring their learners to read. At least, 'Do the homework, and postponing the grammar' were minimized, if not avoided. The study found that teachers' beliefs and awareness of an integration between grammar and reading steadily growing and changing to show that teaching them in an integration would benefit both the teachers and the students.

\section{Limitations of the study}

There is no previously conducted research in this area in Ethiopia. Thus, it was not easy to organize the literature and fixing the setting to establish the base for conducting the teachers' awareness and beliefs of integration the grammar with other skills in depth. Employing only qualitative methodology might be the other limitation for this article as it may affect generalization. With these reasons, it would be recommendable to conduct further study in the areas by adding the students as a sample on the same topic.

\section{Conclusion}

The research on this specific study concluded that the majority of the participants held strong beliefs of grammar and teaching about reading. However, they lacked to demonstrate with an explicit understanding of beliefs and awareness to make an integration between grammar and reading. Teachers also had insufficient exposure to and an understanding of alternative instructional practices, being unable to recall any specific training in reading and grammar instruction. Since the study employed purely the qualitative method of data collection, it might be difficult to extend the conclusion beyond the studied sample groups, i.e. not generalizable. The data from FGD mismatched with what observed and reviewed from the document about their beliefs and practices. Language teachers teach in accordance with their theoretical beliefs and the differences in theoretical beliefs may result in differences in the nature of literacy instruction (Borg, 2003; Borg, 2006). Despite the participant number was not large, their varied experience in teaching and the working area and the inclusion of novice and veteran teachers maximize the quality of the research. The study suggests that since there is a lack of resources that affects the interest in identifying the problems of the teachers in research in Ethiopia; as a result, instructors have little information that can help them to upgrade their teaching ways. It was revealed in this study when the teachers improve their awareness of integrating the two items, students also benefit. Therefore, teachers are encouraged to expose themselves to the awareness of an integration of grammar and reading. However, their firm stand beliefs about the grammar and reading also play an indispensable role. The point is grammar needs reading and reading needs grammar to teach a language.

\section{Acknowledgement}

As this article was the part of my $\mathrm{PhD}$ project, it was funded by BOF under the supervision of Professor Miriam Taverniers, Dr. Kimberley Mouvet from Linguistics Department of Ghent University and Dr. Getachew Seyum from Jimma University, Ethiopia. I thank all EFL teachers of Jimma, Oromiya region for their unreserved participation.

\section{References}

Alderson, J.C. (1984). Reading in a foreign language: a reading problem or a language problem. In Alderson, C\& Urquhart, A. H. (Eds.), Reading in Foreign language (pp. 114- 141). London: Longman.

Bernat, E. \& Lloyd, R. (2007). Exploring gender effect on EFL learners' beliefs about language learning. Australian Journal of Educational \& Developmental Psychology, 7: 79-91.

Biesta, G.J.J. \& Burbules, N.C. (2003). Pragmatism and educational research. Lanham, MD: Rowman and 
Littlefield.

Borg, S. (1998). Teachers' pedagogical systems and grammar teaching: A qualitative study. TESOL Quarterly, 32(1), 9-38.

(2006). Teacher cognition and language education: Research and practice. London: Continuum.

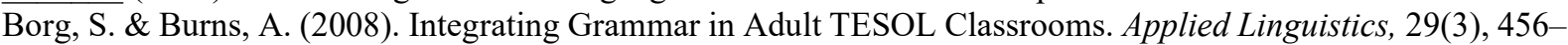
482.

Burns, A. (2003). 'Grammar as "poison"” or "fishing"? - Developing an Australian distance- learning course in systemic functional grammar' in D. Liu, and P. Master (eds): Grammar Teaching in Teacher Education. Alexandria, VA: TESOL.

Carter, R., \& McCarthy, M. (2006). Cambridge grammar of English: Spoken and written English grammar and usage. Cambridge: Cambridge University Press.

Celce-Murcia, M., \& Olshtain, E. (2000). Discourse and context in language teaching: A guide for language teachers. Cambridge: Cambridge University Press.

Creswell, J.,W. (2007). Research design. Qualitative and mixed methods approaches. London: Sage.

Crystal, D. (1996). 'The past, present and future of English rhythm.' In M., Vaughan-Rees, Changes in Pronunciation, Summer 1996 Issue of the Newsletter of the IATEFL Pronunciation Special Interest Group, 8-13.

(2004). Making sense of grammar. Essex: Pearson.

De Capua. (2008). Grammar for Teachers: A Guide to American English for Native and Non-Native Speakers. College of New Rochelle. New Rochelle, NY 10805.

Ellis, R. (2002). The place of grammar instruction in the second/foreign language curriculum. In Hinkel, E. and Fotos, S. (eds.) New Perspectives on Grammar Teaching in Second Language Classrooms. pp. 17-34. Mahwah, New Yersey: Lawrence Erlbaum Associates.

(2003. Task-Based Language Learning and Teaching. Oxford: Oxford University Press.

(2006). "Current Issues in the Teaching of Grammar: An SLA Perspective," in TESOL Quarterly, 40, 83-107.

Grabe, W. (2009). Reading in a second language: Moving from theory to practice. New York: Cambridge University Press.

Heugh, K., Diedericks, G., Prinsloo, C., and Herbst, D. (2007). Assessment of the language and mathematics skills of grade 8 learners in the Western Cape in 2006. Human Sciences Research Council: Pretoria.

Hudson, R. (2001). Grammar teaching and writing skills: The research evidence.Syntax in the Schools, 17, 1-6.

Jean, G \& Simard, D. 2011. Grammar teaching and learning in L2: Necessary, but boring? Foreign Language Annals, 44.3: 467-94.

Jeon, E. H., \& Yamashita, J. (2014).L2 reading comprehension and its correlates: A meta-analysis. Language Learning, 64(1), 160-212.

Kern, R., (2010). Literacy and Language Teaching. Oxford: Oxford University Press.

Kumaravadivelu, B., (2012). Language Teacher Education for a Global Society: A Modular Model for Knowing, Analysing, Recognizing, Doing and Seeing. London: Routledge.

Krashen, S. D. (1993). The case for free voluntary reading. Canadian Modern Language Review, 50(1), 72-82.

Kuzborska, I. (2011). Links between teachers' beliefs and practices and research on reading. Reading in a foreign language, 23(1), 102-128.

Larsen-Freeman, (2003). Teaching language: From grammar to grammaring. Boston: Heinle.

Lincoln, Y. S., \& Guba, E. G. (1985). Naturalistic inquiry. Newbury Park, CA: Sage.

Loewen, S., Li, S., Fei, F., Thompson, A.,Nakatsukasa, K., Ahn, S., et al. (2009). Second language learners' beliefs about error instruction and error correction. Modern Language Journal, 93, 91-104.

Mitchel, R. (2000). Applied Linguistics and evidence-based classroom practice: The case of foreign language grammar pedagogy. London: Prentice Hall.

Ministry of Education. (2017, November). General Education Quality Improvement Package (GEQIP). Addis Ababa, Ethiopia: Ministry of Education.

Myhill, D. A. (2010a). Ways of knowing: grammar as a tool for developing writing. In T. Locke (Ed.), Beyond the grammar wars: A resource for teachers and students on developing language knowledge in the English/literacy classroom (pp. 129-148). London: Routledge.

Nassaji, H., \& Fotos, S. (2004). Current developments in research on the teaching of grammar. Annual Review of Applied Linguistics, 24,126-145.

Nespor, J. (1987). The Role of Beliefs in the Practice of Teaching. Journal of Curriculum Studies. 19 (4), 317 328.

Nunan, D. (1992). Collaborative Language Learning and Teaching. Cambridge: Cambridge University Press.

Pajares, M. F. (1992). Teachers' beliefs and educational research: Cleaning up a messy construct. Review of 
Educational Research, 62, 307-332.

Randi, R. (2016). Grammar Activities for Listening, Speaking, Reading, and Writing published on Webinar: Cambridge University.

Rose, D. (2006). Reading genre: a new wave of analysis. Linguistics and the Human Sciences 2(2), 185-204.

Shiotsu, T., \& Weir, C. J. (2007). The relative significance of syntactic knowledge and vocabulary breadth in the prediction of reading comprehension test performance. Language Testing,24 (1), 99-128.

Stern, H.H,. (1992). Issues and options in language teaching. Oxford, England: Oxford University Press.

Thornbury, S. (1999). How to Teach Grammar. Essex: Pearson Education Limited.

Urquhart, S. \& Weir, C. (1998). Reading in a second language: Process, product and practice. New York: Longman. Watson, A. (2012) First-language English Teachers' Beliefs about Grammar and the Relationship of Espoused Beliefs to Pedagogical Practice PhD thesis: University of Exeter on-line - http://hdl.handle.net/10036/3719.

Zain, M., \&Rohani, S. (2007). Teaching of Grammar: Teachers' Beliefs, Instructional Contexts and Practices. Unpublished doctoral dissertation. Kuala Lumpur, Malaysia: Universiti Kebangsaan Malaysia.

\section{Analyzed Textbooks}

English for Ethiopia Student Textbook Grade 10.

English for Ethiopia Student textbook Grade 9. 